\title{
ACCOUNTING INFORMATION FOR MANAGING SUSTAINABLE HEALTH-TOURISM PRODUCT IN THE TOURISM DESTINATION
}

\author{
Milena Peršić \\ Lahorka Halmi
}

https://doi.org/10.20867/tosee.05.4

\begin{abstract}
Purpose - The purpose of this paper is to explore the adaptation of integrated reporting (IR) model to the specifics of health-tourism services in the tourism destination, with a particular emphasis on complying with the stakeholders' attitudes, sustainability development and corporate governance principles.

Design - After the introduction and the literature review, the content will be focused on testing the hypothesis "Information provided by integrated reporting (IR) system is relevant in assessing recognition and competitiveness of destination's health-tourism product", and for preparing IR model for health-tourism destination.

Methodology - Spearman's correlation coefficient will be used to prove the hypothesis based on the results of survey conducted in 2018 in the tourism destination Kvarner, which has been recognised in the Croatian strategic documents as the destination with great potential for health tourism development.

Approach - To apply a methodological framework of integrated reporting (IR) to the specifics of health-tourism services in the tourism destination, adhering to the principles of corporate governance (destination is considered as a corporation).

Findings - Designing management information system relevant to short- and long-term decision making, according to the destination management and the stakeholders' specific needs.

Originality of the research - Originality can be recognised as a theoretical contribution to the strategic accounting through developing the specific model of integrated reporting for healthtourism products in the health-tourism destination. This approach is also relevant from the practical point of view because it shows how to recognise capitals on the input side (natural, financial, manufactured, intellectual, human, social and relationship), and how to set up a business model that would create added value.

Keywords Accounting information, Integrated reporting, Health-tourism product, Tourism destination, Sustainability, Stakeholders
\end{abstract}

\section{INTRODUCTION}

The purpose of this research is to explore an integrated approach to reporting that is relevant to the specifics of a health-tourism destination and that adheres to the principles of corporate governance, i.e. manages tourist destination as a corporation. For this purpose in 2018 a survey was conducted in the Croatian tourism destination Kvarner. This destination has been chosen due to its recognition in Croatian strategic documents, being recognised as a destination with the most prosperous potential for development of health tourism. The possibility of achieving strategic goals will be considered, especially 
ToSEE - Tourism in Southern and Eastern Europe, Vol. 5, pp. 547-566, 2019

M. Peršić, L. Halmi: ACCOUNTING INFORMATION FOR MANAGING SUSTAINABLE HEALTH ...

in increasing recognisability and competiveness of the destination's health-tourism services in the global health-tourism market. For this purpose it is necessary to do an overview of health tourism potentials and their improvement by critically reviewing availability and quality of special medical and wellness \& spa services. The starting point is critical observation of relevant sources of information (scientific and professional literature, standards, regulations, best practice examples ...) and the research results obtained by questionnaire, carried out on the representative sample of health-tourism institutions (health spas, special hospitals, wellness/spa hotels, wellness centers in the destination, dental and medical clinics, tourism organizations et al.), presented from the point of strategic reasoning and supported by the integrated information system.

\section{RESEARCH BACKGROUNDS AND LITERATURE REVIEW}

In order to extend season by expanding the range and rising quality of health-tourism services in the tourism destination is currently of growing interest to the destination management. Health tourism is an umbrella term for medical, wellness and spa services. Medical tourism is primarily oriented towards curative treatments, whereas wellness and spa services are oriented towards prevention. Specifics and development trends should be considered separately, taking into account the position of health tourism in strategic documents of the EU and Croatia (EUROPE 2020; EU Directives; EU TAP 2013; Health Programme 2014; TE 2010, EuropeNo1 and CNHCS 2012; CTDS 2013; APHTD 2014 ...), as well as regional / destination level (KSOTMP 2016; RDS 2015; RSHID 2013).

Medical tourism is connected with the travel outside the individual's home region or country in pursuit of medical care to obtain medical diagnostic, curative treatments, dental care, surgical and similar medical procedures (cosmetic and other kinds of surgery), fertility treatments, medical wellness, cosmetic treatments and different other non-surgical procedures (Hamlin 2012, 529-530; Ruggeri, Zališ, Meurice, Hilton, Ly, Zupan and Hinrichs 2014, 785). Main motives are lower costs (affordable prices), availability and quality of some treatments, possibility of reducing waiting times, most commonly combined with a vacation in the destination country (Hamlin 2012, 529; Jonson and Garman 2010, 172; MT FAQ 2017, 1-2). Medical tourism is increasing yearly by 15-25\% (Youngman 2018; MTT 2017, 90; PBB, 2014; Woodman 2016).

At the destination level, medical tourism can contribute to an increase of health service quality and access to certain treatments by making available new facilities to local residents. At the same time it may cause health care availability limitations to local residents if professionals devote more of their time to the treatment of foreigners, rather than to needs of local communities. Medical tourism is expected to be globally expanding, primarily due to the improved availability of health technology, decreased travel costs and increase of information availability, if legal protection, safety and security are provided. The significant role of government is in supporting and improving medical tourism policies, directed at improving access, quality of care, health equity through balance of professional and ethical issues in daily medical tourism practice (Bell, Holliday, Ormond and Mainil 2014, 284-289; Hamlin 2012, 529-534; Johnston, Crooks, Snyder and Kingsbury 2010, 1-24; Ruggeri at al. 2014, 785 - 789; Snyder, Crooks, Johnston and Kingsbury 2013, 233-242). 
ToSEE - Tourism in Southern and Eastern Europe, Vol. 5, pp. 547-566, 2019

M. Peršić, L. Halmi: ACCOUNTING INFORMATION FOR MANAGING SUSTAINABLE HEALTH ...

As a part of health-tourism destination product, wellness/spa services are very important for health tourism development, which is usually following the model of "six dimensions of wellness" (NWI 2012). The motive of travelling is a need for preventing or maintaining one's own health or the health of a family member, with a condition of a minimum single night stay and use of benefits directed towards improving the state of body, mind and spirit, and improving overall social wellbeing (Johnston, Puczko and Smith 2011, 12; Voigt et. al, 2010, 9). Wellness and spa services today are considered to be a very important part of disease prevention (Deloitte 2015; GWS 2015, 1-12; GWTR, 2018) and at the same time they make a significant source of revenue for all of the participants involved in preparing and offering health-tourism product. Economic effects for providing various health-tourism services, as a part of integrated health-tourism product, are presented in the next figure.

Figure 1: Economic effects of providing various health-tourism services

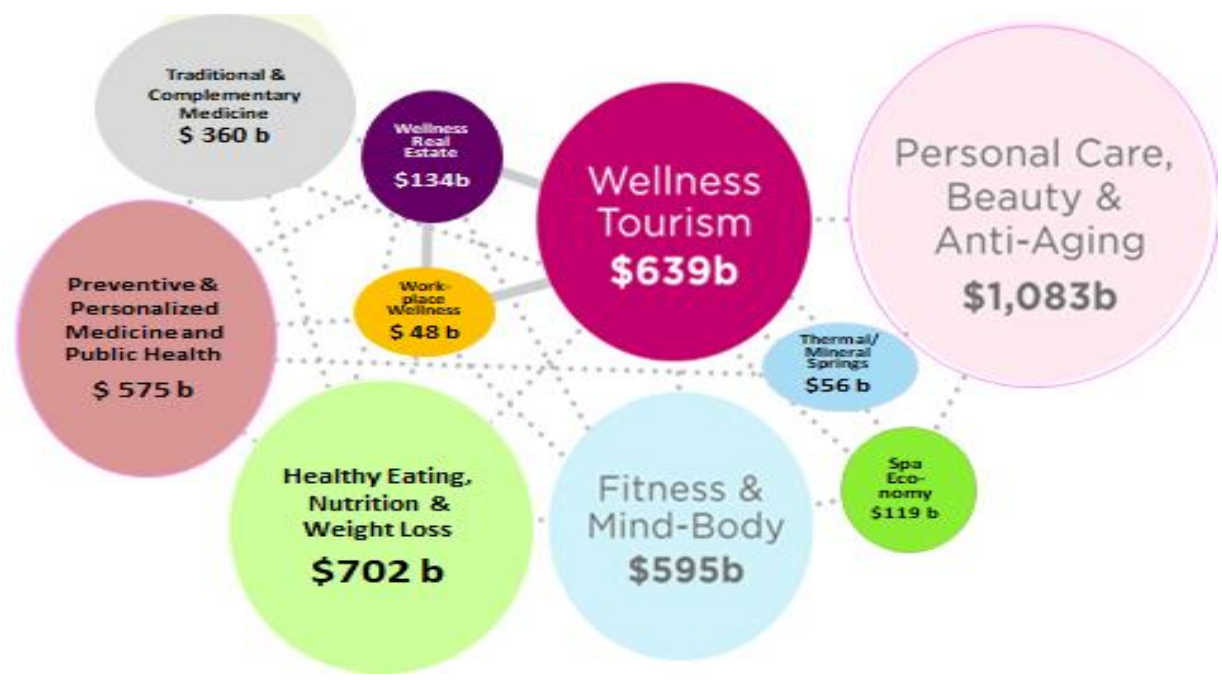

Source: GWS \& GWI, 2018, picture 2

Considering it from a standpoint of revenue earning, anti-aging services dominate globally (25\%), followed by services of healthy eating, nutrition and weight loss (16\%), wellness tourism (15\%), fitness \& mind body treatment (14\%), preventive and personalized medicine supported by public health services (13\%), complementary and alternative medicine $(8 \%)$, whereas other kinds of health tourism services are not so profitable (GWS \& GWI, 2018, picture 2). It can be also noted that a constant growth rate in health tourism field is globally present, which in past ten years has been between 8.3 and $8.6 \%(\mathrm{GOH} \mathrm{2014,7)}$ and it is estimated that an average annual growth rate by 2022 will be $7 \%$. Significant growth is expected in wellness tourism $(7,5 \%)$, thermal / mineral springs $(6,5 \%)$, spa facilities $(6,4 \%)$, and a step forward will be in a field of workplace wellness $(6,7 \%)$ and especially in wellness real estate with $8 \%$ of growth (GWI 2018). Data reported in absolute amounts of globally realized incomes can provide a clearer understanding. The global market revenue in health tourism was in 2010 about \$1,9 trillion (GSS 2010), in 2015 recorded \$3,7 trillion (GWE 2018), and in 2017 it was $\$ 4,2$ trillion, and in between 2015 and 2017, the growth was 12,8\% (GWEM 2018). 
ToSEE - Tourism in Southern and Eastern Europe, Vol. 5, pp. 547-566, 2019

M. Peršić, L. Halmi: ACCOUNTING INFORMATION FOR MANAGING SUSTAINABLE HEALTH ...

Spa services support successful provisions of wellness and medical services in a healthtourism destination, but their content differs significantly between the USA and Europe. Most services provided today are "day spa", "sport \& fitness spa", "club spa", "salon spa", "spa hotels", "spa resorts", "health spa", "medical spa" "eco spa", "historical spa etc. (Garrow 2009, 4; Gee 2010, 38-43 \& 48-57; ISPA 2015; Keck 2010, 7-11; Rulle 2008, 25; Speier 2011, 55-66). Changes in society have a significant impact on the trends in wellness / spa services that are prevention oriented, but make a qualitative part of health tourism product. Based on the debate results of more than 600 wellness experts from more than 40 nations, the top wellness trends for 2018 are presented through the following approaches: (1) Mushrooms emerge from underground, (2) A new era of transformative wellness travel, (3) Reframing the first 1000 days, (4) The wellness kitchen, (5) Clean air act, (6) Extreme wellness, (7) Wellness meets happiness and (8) The new feminist wellness (GWS 2018, 1-90).

Generally speaking, existing trends emphasize that spa services should adapt the philosophy of wellness focusing on regeneration the mind, body and spirit (Tabacchi 2010, 114). Yet, trends are not static and are constantly being developed and upgraded, so the newest Global Wellness Trends Report defines the following trends for 2019 year (GWTR, 2019, 2-109):

(1) Well fashion - Way beyond athleisure (A new era of sustainable, ethical, intelligent, healing, more inclusive and meaningful clothing is on the rise);

(2) Wellness takes on overtourism (With overtourism the \#1 issue facing the trave industry today-wellness tourism will provide an antidote, pulling people to less trafficked, healthier destinations);

(3) Meditation goes plural (People get clearer about the core meditation types and their unique brain impacts as this explosive market also blooms into many varietals);

(4) Prescribing nature (There is enough science about the health benefits of nature to get the attention of the medical profession);

(5) MediScent__Fragrance gets a wellness makeover (A new understanding of scent's crucial role in our physical and emotional wellbeing);

(6) China _ uncovering the wealth in wellness (Suddenly an economic, political and tech powerhouse, China will be a force that transforms the wellness market);

(7) Nutrition gets very personalized (Diet confusion, new tech and the "power of me" propel personalized nutrition into mainstream);

(8) Dying well (Dying is finally becoming part of the wellness conversation, and everything around death is getting rethought from what a healthy end-of-life looks like to a surge in eco-friendly and creative burial options).

Aiming to accept demands of global trends, it is also necessary to follow the scenarios for health tourism development prepared by the relevant EU bodies. Therefore, a Policy Directorate General for Internal Policies as a part of Department for Structural and Cohesion Policies of European Parliament in field of Transport and Tourism adapted the following policy (Mainil at al. 2017, 10):

,A policy scenario aiming at enhancing health in the EU through further developing and integrating health tourism and healthcare and using the opportunities for prevention rather than cure may have a better potential for the general good than a scenario aiming at just economic growth of the health-tourism market. The latter may provide benefits to 
ToSEE - Tourism in Southern and Eastern Europe, Vol. 5, pp. 547-566, 2019

M. Peršić, L. Halmi: ACCOUNTING INFORMATION FOR MANAGING SUSTAINABLE HEALTH ...

the economy, but it may also come with a risk of increased cost for the regular healthcare systems. In a scenario where health policies prioritize improving health, there is a role for the tourism and hospitality sector to cooperate with the health sector by exchanging experiences and requirements for accommodation, transport, services, employee competences, etc. that help to facilitate accommodation and mobility for less-abled visitors or visitors requiring special treatments".

In establishing a reporting system for internal and external users in the wellness/spa area of services, standard ISO 17679:2016 could be very important, because it recognises requirements of a wellness/spa services, points out main supporting processes and the quality of service to be provided to the client. It can also be used by all types and sizes of wellness / spas subjects, even if they are organised as an integral part of another kind of activity (e.g. accommodation facilities, fitness centres and hospitals). It is some kind of upgrading medical tourism services, but it does not apply to medical spas and thalassotherapy centres if it is related to medical professions, medical training or any religious aspects (ISO 17679, 2016). A good understanding of the specifics of all health tourism elements and users information needs is essential in the process of establishing integrated reporting system. It is also very important to use modern informationcommunication technology (ICT) in presenting the possibility of health-tourism destination at the global health-tourism market (MTDG 2015).

An important approach is using "customer centric technology" (Buhalis and O'Connor $2005,11-12)$ as a qualitative support in decision making processes. The research based on observations and analysis of 57 research journals, indicates that managers should integrate possibility of ICT in daily business and reporting system, because it can successfully support the business, and maximize its full potential (Law, Leung and Buhalis 2009, 599-623). Special emphasis should be placed on e-marketing activities (Lončarić and Radetić 2015, 15-26) in creating a way of communication with the global health tourism market. It is important to accept the ICT potentials, since approximately $43 \%$ of the population is constantly being online, the number of internet users in developing countries has almost doubled in the last five years, and the number of mobile cellular subscriptions has tripled in the past 10 years (ITU 2016, 5).

ICT is embedded in e-tourism trends and is very important in supporting health tourism guest and their families in choosing where to use medical, wellness or spa services, combining these services with attractive locations with the recognisable natural resources, heritage and other attractions (Deloitte 2008, 5-6; DMT 2011, 1-3; Hall 2011, 5-6; Smith and Puczko 2009, 101; Voigt at al. 2010, 36). The primary purpose of an integrated report is to explain to financial capital providers how an organization creates value over time, taking into account the specifics of health-tourism product. The best way to do so is through a combination of quantitative and qualitative information, which is where the six capitals (natural, human, manufactured, financial, intellectual, social and relationship) come in. The capitals are stocks of value that are affected or transformed by the business model of specific health-tourism activities and in creating added value on the outputs side of the destination level. An organization's business model draws on various capital inputs and shows how its activities transform them into outputs (IIRC 2016; IR Framework 2013, 5;) as is presented in figure 2. 
ToSEE - Tourism in Southern and Eastern Europe, Vol. 5, pp. 547-566, 2019

Figure 2: Integrated reporting framework

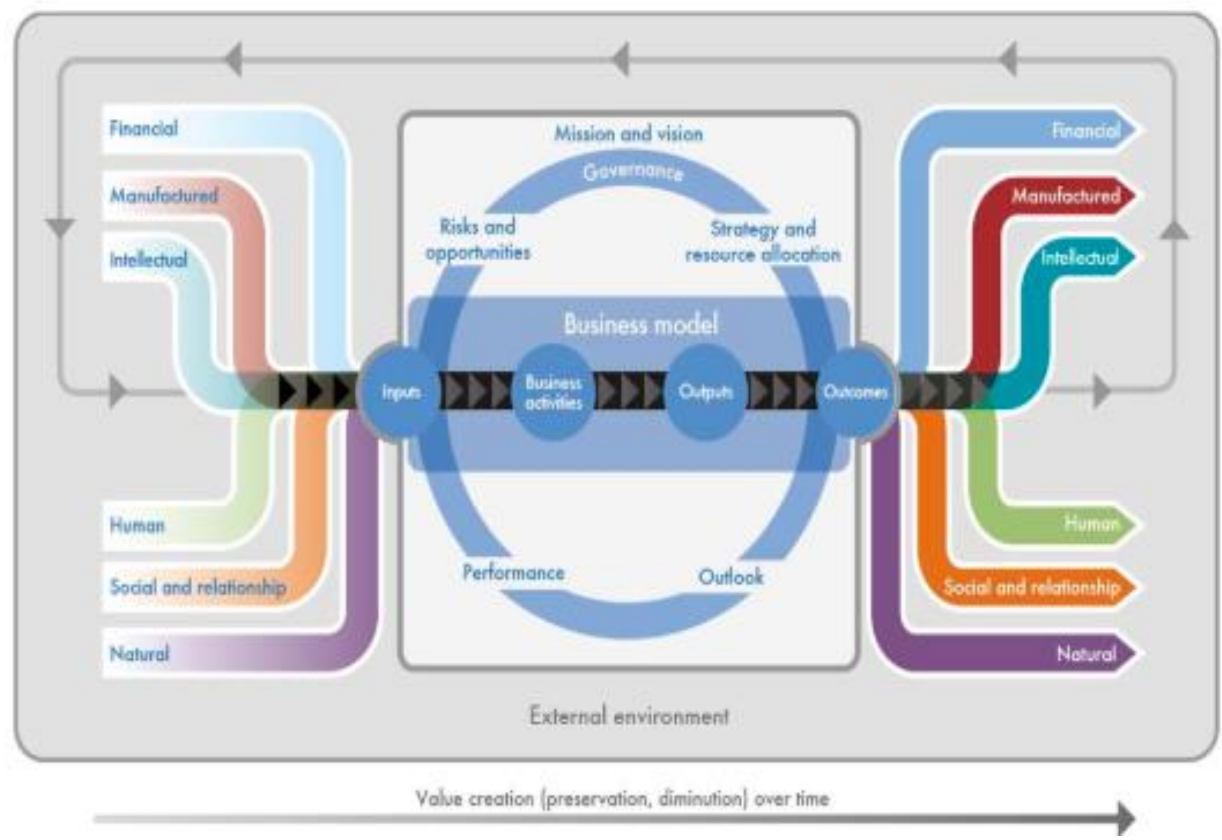

Source: IR Framework 2013, 13.

Using the integrated reporting framework it is possible to present for a health-tourism destination, how availability of certain capitals on the input sides (resources), and the chosen business model, contribute to the success of a health-tourism destination in the tourism market. In applying integrated reporting model, the health-tourism destination is observed as a corporation. This is to be a generic model (IIRC 2013) adapted to the specific requirements of health-tourism destination management and stakeholders.

Integrated reporting in the health-tourism destination presents a business model in creating recognizable destination health-tourism product (package), which consists of a series of specific / recognizable services prepared by various providers, which could be seen as a strategic business units - SBU (Hoque 2006, 32), whose connectivity and compliance is guaranteed by using ITC. Integrated reporting places special attention to the relationship between destination strategy and value creation of all participants over time (Khan, Serafeim and Yoon 2015, 1-37; IR 2016). Following the theoretical framework, it is necessary to consider specific goals and policies, which are directly related to destination's health-tourism development in accordance with the global trends and EU scenarios in such a way to ensure comprehensive and useful information for destination management, stakeholders and investors (Eccles and Serafeim 2014, 14-15).

In the process of preparing integrated report for the health-tourism destination's needs, special attention should be given to "materiality" as the most important part in selecting, connecting and assessing the relationships among different information (Mio 2016, Fig 1.1.), following the value chain approach in creating specific business model (Eccless, Serafeim 2014, 15-16). It is also important to respect the boundaries and limitations in 
ToSEE - Tourism in Southern and Eastern Europe, Vol. 5, pp. 547-566, 2019

M. Peršić, L. Halmi: ACCOUNTING INFORMATION FOR MANAGING SUSTAINABLE HEALTH ...

achieving the long-term efficiency, environmental and social responsibility (Hoque 2017, 241-248). In creating materiality matrix, each health-tourism institution (as part of the destination health-tourism product) could follow common health-tourism destination policy, which takes into account destination management and stakeholders needs (IIRC 2016, 10-20) and health-tourism global trends, scenarios and the sustainable development principles.

Reliability, completeness, consistency, comparability and connectivity are important qualitative characteristics of the information (IR 2016, 20) which should be followed in the process of preparing the destination's integrated report. Integrated reporting should also be focused on demonstrating a compliance of the achieved results with legal and other requirements and health tourism development strategic goals, defined in the framework of relevant national and regional strategic documents, as well as achieved level of practice development (Peršić 2012; Peršić and Janković 2012; Peršić and Janković 2014; Peršić, Vlašić and Janković 2016; Peršić and Halmi 2016; Peršić and Vlašić 2017).

\section{RESEARCH METHODOLOGY AND FINDINGS}

Data for this research was gathered through questionnaire specifically designed for the purpose of assessing the achieved level and the possibilities of further development of health-tourism in the Kvarner tourism destination. This destination was chosen because it has been recognized in Croatian strategic documents as the county with significant potentials for the development of all health-tourism segments (APHTD 2014; CNHCS 2012; CTDS 2013). An online questionnaire was sent to the 82 health-tourism institutions at the beginning of 2018, with an aim to assess the attitudes of responsible management of health/spa resorts, special hospitals, thalassotherapies, wellness/spa hotels, medical and/or dental clinics, tourist boards and tourist organizations, most of which were members of the Kvarner Health Tourism Cluster (Persic 2018, 18). The response rate was $56,10 \%$ (46 out of 82 ).

In order to assess the state and possibilities of developing health tourism at a level of the Kvarner destination, a Likert scale ( 1 = extremely low; $5=$ extremely high) was applied in the questionnaire that was sent out to the managements responsible for health and tourism institution involved in providing the offer of health-tourism services. Along with the closed-ended (provided) questions, the respondents were able to answer some questions providing their own suggestions / proposals and relevant explanation. The purpose of this research was to prove the hypothesis "Information provided by integrated reporting system is relevant for assessing recognition and competitiveness of destination's health-tourism product". To prove the hypothesis, variables were defined in the way to evaluate the relationship between availability of capitals on the input side of health-tourism destination, and the ability for creation of new value, as a prerequisite for achieving desired levels of recognition, competitiveness and sustainability of destination's health- tourism product, which is basically a fundamental concept of integrated reporting. The significance/importance of some capitals on the input side of integrated reporting at the health-tourism destination level has been evaluated. The relationship between perceived significance / importance of elements of the health- 
ToSEE - Tourism in Southern and Eastern Europe, Vol. 5, pp. 547-566, 2019

M. Peršić, L. Halmi: ACCOUNTING INFORMATION FOR MANAGING SUSTAINABLE HEALTH ...

tourism services on the tourist destination level today and perceived recognition and competitiveness of the Kvarner tourism destination was investigated using Spearman's correlation coefficient.

The starting point is consideration of elements as influential factors of the health-tourism destination environment, which are recognized in the integrated reporting as capitals on the input side. Natural capitals are in average the best positioned elements on the input side, because in the first place is natural beauty, climate, clean air and water $(4,57)$, unpolluted and preserved environment and horticultural heritage; (4,30), pleasant surroundings without the noise $(3,96)$, natural healing factors $(3,39)$. Social capital and relationship are primarily recognized through high level of general and personal security of visitors at the destination level $(4,52)$, through availability of cultural and historical heritage $(3,80)$ as well as in recognizable tradition and folk customs $(3,41)$.

For health tourism development it is also of great importance the quality of human capital, which is in this destination well positioned, because the following has been recognized: the level of foreign language skils of employees in tourism $(3,91)$, kindness of employees in tourism sector $(3,91)$, knowledge and professionalism of employees in the health-care sector $(3,78)$, knowledge and professionalism of employees in the tourism sector $(3,76)$, communication skils and kindness of citizens $(3,65)$, high quality of human resources in area wellness/spa services $(3,54)$, foreign language skils of citizens $(3,48)$. It should be noted that employees in the field of health-care sector are somewhat worseranking if observed by the level of knowledge of foreign languages $(3,2)$, or in the segment of recognized extraordinary experts for specific medical treatments $(3,00)$, and lacking the availability of specific educational and lifelong learning programs $(2,93)$ for health tourism development.

Manufactured capital presented through available physical objects and possibility which support provision of health-tourism services are more or less presented at the destination level. This destination has geographically favourable traffic position $(4,37)$ as well as good availability and quality of transport infrastructure $(3,83)$. But, the other supporting infrastructure is not satisfactory, namely level of beaches equipment $(3,17)$ should be improved, as well as the sports recreational facilities in the surrounding (3) and in urban areas $(2,85)$, and there is also a need for significantly greater investment in the use of modern technologies in medical tourism $(2,89)$.

Intellectual capitals is recognizable through high quality of authentic local cuisine $(3,61)$, but not enough supported by fisheries and organic agriculture $(3,22)$. Local autochthonous products and souvenirs $(3,24)$ and natural healing products $(2,87)$ are not at a satisfactory level. It is also necessary to improve the level of wellness / spa services in the independent centers $(2,93)$ and in the destination as a whole $(3,20)$, because they are at a lower quality level than such services in hotels $(3,50)$. The achieved level of services in medical tourism $(2,82)$ is not satisfactory, as well as the recognisability of medical treatments $(2,96)$, which means that there is a need of certifications and accreditations of the health-tourism institutions business $(2,70)$. Taking into account the characteristics of capital on the input side, specifics of the medical tourism services and wellness / spa tourism services at the destination level will be thoroughly investigated and evaluated. Attributes of individual capitals on the input side have impact on forming 
ToSEE - Tourism in Southern and Eastern Europe, Vol. 5, pp. 547-566, 2019

M. Peršić, L. Halmi: ACCOUNTING INFORMATION FOR MANAGING SUSTAINABLE HEALTH ...

a business model, and provides preconditions for developing health tourism product at a destination level. Evaluation of availability of different kinds of health tourism services at the destination level are based on following two variables:

a) Evaluation of the availability and/or achieved level of medical tourism services quality;

b) Evaluation of the availability and/or achieved level of spa / wellness / wellbeing services quality.

An option "does not exist" was provided in questions referring to the quality of medical tourism services, as well as for the group of spa / wellness / selfness / wellbeing services. Although some elements were evaluated as non-existent, these were coded as 0 (zero) and did not affect the computation of the correlation coefficient. Two variables measuring the recognition and competitiveness of the destination had an option of listing few more services than those just mentioned as well as evaluating them on a Likert scale. Since there was just one suggestion referring to the question of evaluation of the availability and/or achieved level of health-tourism services quality for medical tourism and was lowly rated, this response and options of open-ended questions were discarded in further analysis. The results of the research are presented below.

Results of evaluation at the destination level show that dental care $(4,50)$ is the most developed and recognized as a high quality type of medical tourism services. Next to it are positioned medical diagnostics, surgery and rehabilitation (locomotor system, heart and blood system, respiratory system), aesthetic surgery and treatments $(3,29-3,15)$, following by other kind of surgical procedures, ophthalmology care of old and helpless people, treatment of patients with severe / chronic diseases and organs transplantation $(2,76-2,49)$. The following medical tourism services are considerably less present in the structure of destination health-tourism product: head and brain surgery, treatment of noncommunicable diseases, chemotherapy, diabetes treating, radiotherapy and holistic approach to treatment $(2,41-2,10)$. At the very end are positioned the following medical -tourism services: alternative medicine (diagnostic / treatments), treatment of rare diseases (adults /children), TCM (Traditional Chinese Medicine) and fertilization, gender change and related services $(1,98-1,44)$.

Among wellness/spa services none can be singled out by their quality/recognition and being a motive for visiting this destination. Namely, in the first place is positioned fitness $(3,55)$, followed by programs for facial and body care, therapies of movement (yoga, aerobic, dance, tai chi ... ), health / beauty programs $(3,32-3,20)$. Healing sea and air based treatments and prevention programs based on physical activities as services based on natural healing factors are not adequately designed $(3,10-3,00)$. Somewhat lower position take programs in nutrition, healthy eating, healthy food and beverage and diet, anti-aging therapy, combination of healing factors, healthy eating education programs, integral renewal programs, relaxation \& mediation programs, energy therapies / exercises, manipulative therapies (chiropractic, osteopathic ... ), medical problem counselling, spa product retail, ecological programs and health care prevention clubs activities $(2,95-2,51)$. The following programs are marginally represented in the destination health-tourism product: lifestyle changing counselling, manual acupressure, group therapies, pain relief therapies, alternative medicine counselling, education - 
ToSEE - Tourism in Southern and Eastern Europe, Vol. 5, pp. 547-566, 2019

M. Peršić, L. Halmi: ACCOUNTING INFORMATION FOR MANAGING SUSTAINABLE HEALTH ...

mental activities, intercultural programs, healing mud based treatments, meditation and spiritual renewal and health farms (in nature) $(2,49-1,8)$.

Using Spearman's correlation coefficient the relationship between evaluation of the significance / importance of elements of the health-tourism services on the destination level today will be explored. The achieved level and quality of medical tourism services, as well as the spa / wellness / selfness / wellbeing services will be separately considered. The research results will be used in such a way to create integrated reporting model specifically for health - tourism destination (destination as the corporation). In the table are presented results of analysis, based on Spearman's correlation coefficient.

Table 1: Correlation analysis

\begin{tabular}{|l|r|l|r|r|}
\hline & & & availability & \multicolumn{1}{c|}{ destination } \\
\hline \multirow{3}{*}{ Spearman's rho } & \multirow{2}{*}{ availability } & Correlation Coefficient & 1,000 &, $603 * *$ \\
& \multirow{2}{*}{ destination } & Sig. (2-tailed) & &, 000 \\
& & Correlation Coefficient &, $603 * *$ & 1,000 \\
& Sig. (2-tailed) &, 000 & \\
\hline
\end{tabular}

**. Correlation is significant at the 0.01 level (2-tailed). b. Listwise $N=42$ Source: Authors processing

Preliminary analysis was performed to ensure no assumption of monotonic relationship was violated. As the results in Table 1 suggest, there is a strong positive monotonic correlation between these two variables (rho $=, 603, \mathrm{n}=42, \mathrm{p}<0,01$ ). A positive correlation has been noticed between the elements on the input and output side of integrate reporting. It is proven that quality of health-tourism product (structured through medical tourism and wellness/spa services) is strongly connected to the quality of elements which are part of capitals on the input side. Recognising capitals relevant for health-tourism development is very important in designing a business model, which will be used to provide added value, presented / recognised through some groups of capitals on the output side. Using methodological framework of integrated reporting is foundation for preparing information, relevant for assessing recognition and competitiveness of destination's health-tourism product, meaning that the hypothesis "Information provided by integrated reporting system is relevant for assessing recognition and competitiveness of destination's health-tourism product" has been proven.

\section{DISCUSION AND MODEL DESIGNING}

Research results (Persic 2018, 14) indicate that, despite significant assumptions, health tourism development is not yet among the leading motives for choosing the Kvarner tourist destination (average rate 3.04), but has somewhat increased in comparison to the previous survey with the average rating of 2.69 (Blažević and Peršić 2007, 267), which means that additional efforts should be made to improve the current situation. As a particularly significant input into the integrated reporting system at a tourism destination level should be highlighted that natural, and some kinds of human, intellectual and manufactured capitals (natural beauty, climate, clean air and water, preserved environment and horticultural heritage, general and personal security, geographically 
ToSEE - Tourism in Southern and Eastern Europe, Vol. 5, pp. 547-566, 2019

M. Peršić, L. Halmi: ACCOUNTING INFORMATION FOR MANAGING SUSTAINABLE HEALTH ...

favourable traffic position, relevant human resource knowledge and skills) are highly positioned and rated by scores of four and more.

It can be noticed that the quality level of health-tourism services should be improved, and it is recommended to take into account experts' advices professional organizations and association support (KHTC 2014; KHTG 2017; KHW 2012; RSHID 2013). It is also useful to observe and adhere to the positive experiences of the dental tourism development $(4,50)$ at the destination level. Quality should be measured through certificate acquisition and accreditation $(2,71)$ of institutions and services, as a way for market recognisability increase. In the Kvarner tourism destination no particular form of wellness / spa service has been recognized, but it can be noticed that programs connected to the "body needs" dominate and those related to the "spirit and mind" are significantly less present whereas contemporary wellness/spa trends have not yet been recognized (GWS 2018; GWTR 2018, GWTR 2019; Local Measure 2018).

In defining a business model, it is also necessary to have a good knowledge of the framework and opportunities for health-tourism development from the position of a health-tourism destination level. This requires different influences to be considered, such as macro- and microeconomic environment, global trends, standards and guidelines, EU strategies, scenarios and policies, national legislation, strategies, action plans and policies, environmental and sustainability principles, local strategies prepared for the regional / destination level needs, information requirements of management and stakeholders, as well as the health-tourism guests needs and wishes. From the viewpoint of the responsible management in Kvarner tourism destination, the most important projects for health tourism development (which ought to be included in the business model) is thalassotherapy $(4,45)$, because this service provides conditions for integrated approach to services offered, combining benefits of the sea, climate, first class of medical and wellness services, using the possibility of "Kvarner effect of healing" founded on using natural healing factors.

Particular emphasis should be placed on a stronger development of medical tourism, which includes a more intensive orientation towards tourism market through organized marketing tools, creating terms for a more sophisticated level of cooperation between private and public sector (hospitals and clinics). An orientation towards small entrepreneurship is needed as well, so the current level of service quality provided by health/spa resorts and special hospitals would improve. Figure 3 shows the complexity of the relationship and connections on the level of health-tourism destination that are relevant in creating destination health - tourism product. 
ToSEE - Tourism in Southern and Eastern Europe, Vol. 5, pp. 547-566, 2019

M. Peršić, L. Halmi: ACCOUNTING INFORMATION FOR MANAGING SUSTAINABLE HEALTH ...

Figure 3: Level of communication and interconnectivity among health-tourism institutions at a health-tourism destination level

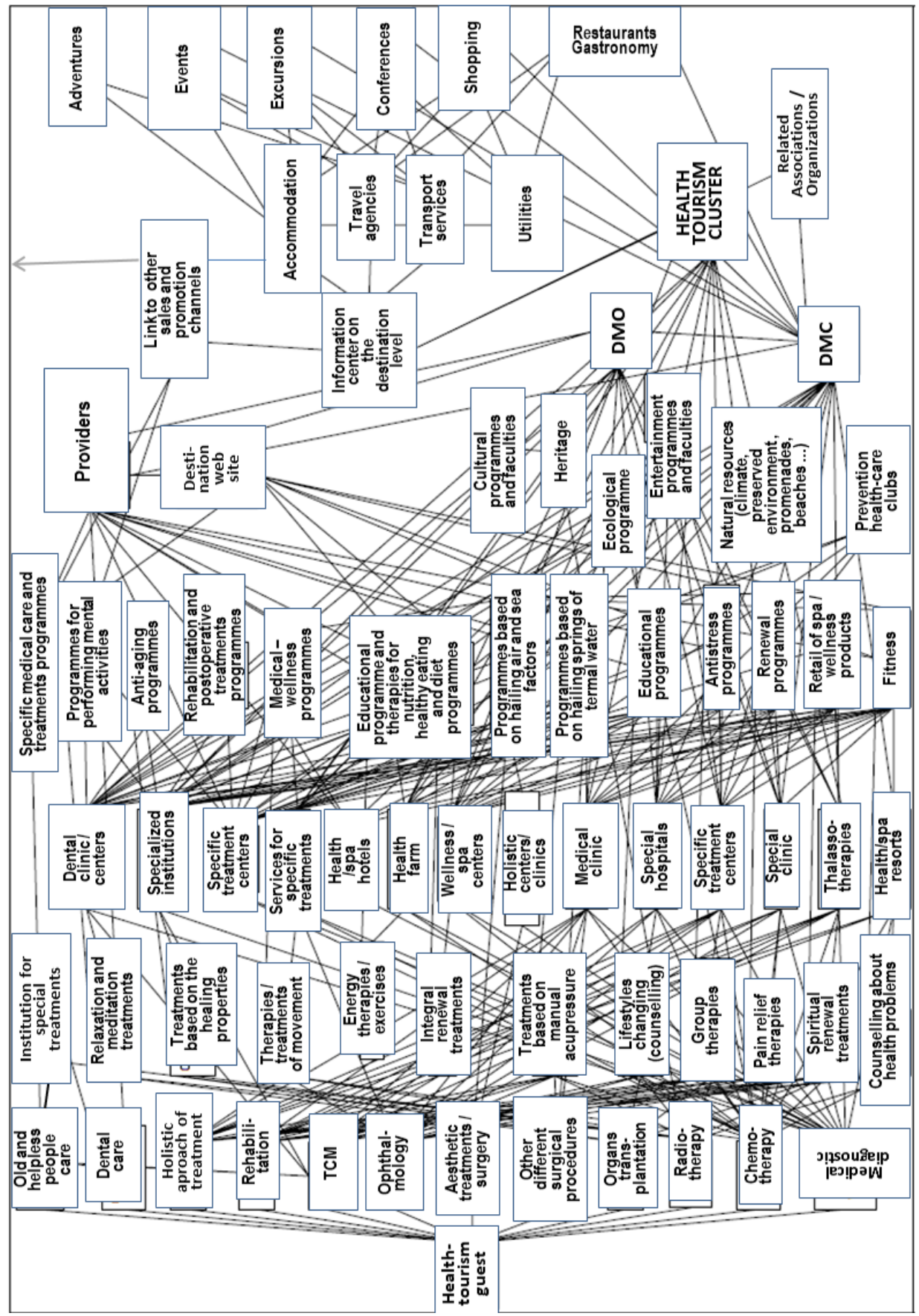

Source: Prepared by authors 
ToSEE - Tourism in Southern and Eastern Europe, Vol. 5, pp. 547-566, 2019

M. Peršić, L. Halmi: ACCOUNTING INFORMATION FOR MANAGING SUSTAINABLE HEALTH ...

Following the suggestions of global trends and EU scenarios, smart specialization and possibilities of complementary / alternative medicine should be more present in the destination health-tourism product, but significant improvements in regulations are needed. Very important is communication between all participants included in preparing high level of health-tourism product, supported by ICT. ICT ought to be applied to a high extent, in order to raise the level of communication and create interconnectivity between health-tourism institutions and health-tourism market as to increase the recognition and competitiveness of the Kvarner health tourism destination. For supporting interconnectivity between different health-tourism institutions in a health-tourism destination, DMO, DMSs and Health Tourism Cluster play a very important role. Namely, health-tourism organisations ought to develop personalized services technology to address individual needs of increasingly demanding and well informed guests of the health-tourism market. The above mentioned assumptions are relevant starting points in creating business model, aimed at creating added value.

Information about previously presented content, links and relationships are a part of integrated reporting model in which integrated thinking is embedded within mainstream business practice of all institution and other participants included in creating, preparation and provision of recognisable destination health-tourism product (consisting of a series of individual medical, wellness and spa services), which are provided at a tourist destination level. Integrated thinking is active consideration and relationship between various operating and functional units at a destination level, taking into account characteristics of the capitals that the institution uses or affects. Integrated thinking takes into account the connectivity and interdependencies between the range of factors that affect an organization's ability to create value over time and present information relevant for decision-making that considers the creation of value over the short, medium and long term (IR Framework 2013, 2).

Special emphasis ought to be placed on presenting the elements connected with the capitals on the input side of health-tourism destination, taking into account key stakeholders' legitimate needs and interests, because it is very important in creating business model and strategy to be oriented towards achieving added value, presented through some kinds the capitals on the outcomes side. A model of integrated report shown in Figure 4 stems from academic theoretical background and survey results of the Kvarner tourism destination. Analysis of the elements presented in the model prepared specifically for health-tourism destination suggests that this approach improves the quality of information on how using the business model could be more efficient and capitals productively allocated on the input side.

Special emphasis is on communication between the full range of factors supported by integrated thinking approach, with the focus on the creation of value over the short, medium and long term. This approach emphasizes communication between a great number of factors, by adhering to the principle of "integrated thinking", thus emphasizing a creation of added value (figure 3). Figure 4 presents an integrated reporting (IR) model relevant to the health-tourism destination. The model is based in the theoretical IR framework and previously presented research results. The emphasis is on presenting the characteristics of capitals on the input and output side, and relevant influential factors on business model and value creation over time. 
ToSEE - Tourism in Southern and Eastern Europe, Vol. 5, pp. 547-566, 2019

M. Peršić, L. Halmi: ACCOUNTING INFORMATION FOR MANAGING SUSTAINABLE HEALTH ...

Figure 4: Model of integrated reporting prepared for the specific of healthtourism product on the destination level

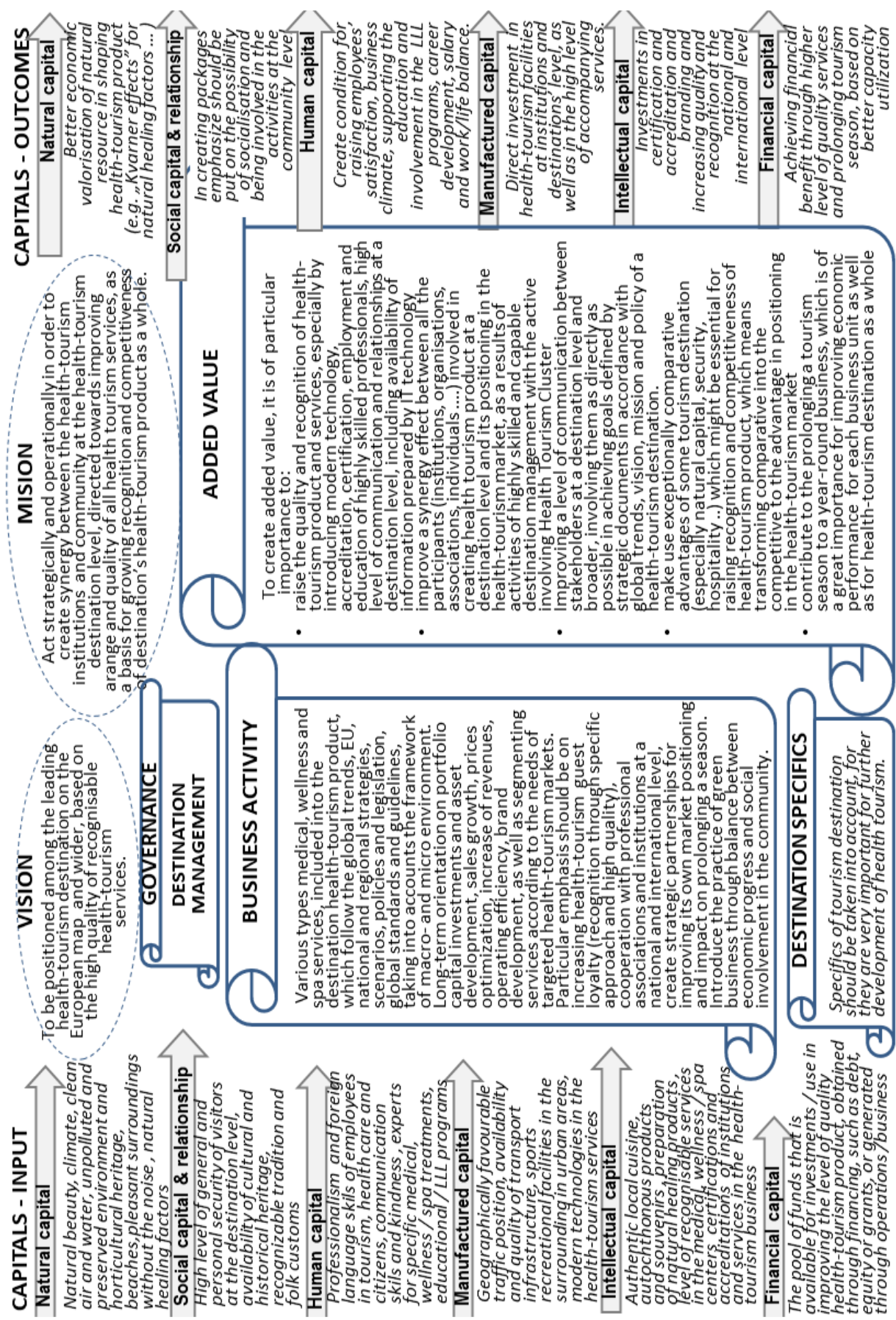

Source: Prepared by authors 
ToSEE - Tourism in Southern and Eastern Europe, Vol. 5, pp. 547-566, 2019

M. Peršić, L. Halmi: ACCOUNTING INFORMATION FOR MANAGING SUSTAINABLE HEALTH ...

\section{CONCLUSION}

This research examined a possibility of applying integrated reporting (IR) to the specific needs of health-tourism business at a destination level, as a source of accounting information for managing sustainable health-tourism product in a tourism destination. Applying integrated thinking at a destination level has also been considered, by presenting relationships between different business units, involved in preparing healthtourism product. IR, as a new kind of reporting, has not yet been developed to meet specific needs of the health-tourism destination. Research results on specific needs of health-tourism management and stakeholders and the IR framework were the starting points in preparing the IR conceptual model by recognising the attributes of capitals on the input sides, influential factors in creation of business model, and how added value can be achieved and presented through capitals on the output side. Since such model has not yet been developed, created specific model of integrated reporting for health-tourism products prepared for the health-tourism destination level can be recognised as a contribution. The limitations of this research are related to the lack of theoretical starting points and practical experience in creating integrated reporting models for specific needs of health tourism product, as well as experiences about possibilities of application at the health-tourism destination level. The model has defined only the key points, with no actual data. Future research should focus on influential factors in the health-tourism destination, which are relevant for application of integrated thinking approach. This primarily refers to using the specific methodological framework in providing information for destination management, relevant for strategic and operative decision making in applying sustainability and corporate governance principles (destination as a corporation), but also in motivating investors to invest in the health tourism development.

\section{ACKNOWLEDGEMENTS}

This paper is a results of research carried out within the framework of the project ZP UNIRI 3/18 "Integrate reporting as a source of information in assessing recognition and competitiveness of the destination's health-tourism product", with financial support of the Faculty of Tourism and Hospitality Management, University of Rijeka.

\section{REFERENCES}

ANPHTD (2014), Action plan - National program for health tourism development // Nacionalni program Akcijski plan razvoja zdravstvenog turizma, Ministry of tourism /Ministarstvo turizma, Institute for tourism /Institut za turizam, Zagreb, viewed 22 February 2017, http://www.mint.hr/default. aspx?id=23908

Bell, D., Holliday, R. Ormond, M. Mainil, T. (2014), "Transnational Healthcare, cross-border perspectives", Soc Sci Med 2015, pp. 284-289, doi; http://dx.doi.org/10.1016/j.socscimed.2014.11.014 PMID: 25467880

Blažević, B. \& Peršić, M. (Eds) (2007), “Assessing the Kvarner Tourism Offering”, Tourism and Hospitality Management, Opatija, Research results of the Project of Ministry of Science, Education and Sport No 0116003 (2002-2006), pp. 1-435

Blažević, B. \& Peršić, M. (Eds) (2012), Tourism Destination Research // Istraživanje turizma destinacije, Faculty of Tourism and Hospitality Management, Opatija, pp. 1-343.

Buhalis, D. \& O’Connor, P. (2005), "Information Communication Technology Revolutionizing Tourism", Tourism Recreation Research, Vol. 30, No. 3, pp 7-16. 
ToSEE - Tourism in Southern and Eastern Europe, Vol. 5, pp. 547-566, 2019

M. Peršić, L. Halmi: ACCOUNTING INFORMATION FOR MANAGING SUSTAINABLE HEALTH ...

CNHCS (2012), Croatian National Health Care Strategy //Nacionalna strategija razvoja zdravstva 2012-2020, Official Gazette - OG 116/2012.

CTDS (2013), Croatian Tourism Development Strategy until 2020, Ministry of Tourism, Zagreb, National Official Gazette - OG - No 55/2013.

Deloitte (2008), Medical Tourism - Update and implications - Consumers in Search of Volume, DCHS - The Deloitte Center for Health solution, viewed 22 December 2'017,

http://www.globalwellnesssummit.com/wp-content/uploads/Industry-Research/Americas/2008deloitte-medical-tourism-consumers.pdf

Deloitte (2015), Global health care outlook - Common goals, competing priorities Deloitte Touche Tohmatsu, viewed January 12, 2017,

https://www2.deloitte.com/content/dam/Deloitte/global/Documents/Life-Sciences-Health-

Care/gx-lshc-2015-health-care-outlook-global.pdf

Deloitte (2018), Health \& Wellness Progress Report Deloitte, The Consumer Goods Forum Health \& Wellness Pillar, viewed January 15, 2018

https://www2.deloitte.com/content/dam/Deloitte/global/Documents/cb-2018-health-wellnessreport-new.pdf

DMT (2011), Discover Medical Tourism “Medical Tourism Guide” viewed 05 July 2017, http://www.discovermedicaltourism.com

DMT (2012), Discover Medical Tourism, Medical Tourism Guide, viewed 05. July 2017, http://www.discovermedicaltourism.com , doi: http://dx.doi.org/10.1002/bse.564

Eccles, R.G. \& Serafeim, G. (2014), Corporate and Integrated Reporting: A Functional Perspective, Harward Business School, Working Paper 14-094, pp. 1-15.

EU Directive (2011), Directive 2011/24/EU on the Application of Patients' Rights in Cross-Border Healthcare, EU Parlament and the Council, Official Journal of the European Union, pp. I- 88/45 - 88/65.

EU TAP (2013), Implementation rolling plan of tourism action- framework based on a new political framework for tourism in Europe COM 352 (2010), viewed 14 February 2015, http://ec.europa.eu/growth/sectors/tourism/ policy-overview/index_en.htm

EUDNFI (2014), Directive 2014/95/EU, Official Journal of the European Union. Text with EEA relevance, viewed 28 May 2018 , http://eur-lex.europa.eu/legal-content/EN/TXT/PDF/?uri=CELEX:32014L0095\&from=HR

EUROPE 2020 (2010), A European Strategy for Smart, Sustainable and Inclusive Growth, European Commission - EUROPE 2020, viewed 20 May 2017, http://ec.europa.eu/eu2020/pdf/COMPLET\%20EN\%20BARROSO\%20\%20\%20007\%20$\% 20$ Europe $\% 202020 \% 20-\% 20 \mathrm{EN} \% 20$ version.pdf

Europe No.1 (2010), Europe, the world's No1 tourist destination - A new political framework for tourism in Europe, Communication from the Commission to the European Parliament, the Council, the European Economic and Social Committee and the Committee of the Regions, European Commission, COM, 352, viewed 22 February 2018, http://eur-lex.europa.eu/legal-content/ EN/TXT/PDF/?uri= CELEX:52010DC0352\&from=EN

EY (2014), Integrated reporting - Elevating value. EY - Building a better working world. EYGM Limited. EYG No. AU2354.

Garrow, S. (2009), SPA Benchmark Report, Global SPA Summit, PPP, viewed 15 January 2015, http://www.prweb.com/releases/ 2009/04/prweb2320724.htm

Gee, Ch. Y.(2010), World of Resorts - From Development to Management, III Ed., Lansing, Michigan, USA, The American Hotel \& Lodging Educational Institute.

GOH, (2014), Global outlook: Healthcare, The Economist, Intelligence Unit, viewed 22 May 2017 https://www.eiu.com/public/topical_report.aspx?campaignid=Industries2014

GSS (2010), SPAS and the Global Wellness Market; Synergies and Opportunities, New York, Global SPA Summit (GSS) and Stanford Research Institute (SRI).

GWE (2018), Global Wellness Economy, Shaping the Business of Wellness, Global Wellness Institute, viewed 18 March 2018

https://us14.campaignarchive.com/?u=3c3105a9b5dd3794bc35e2d8f\&id= $3 \mathrm{a} 420 \mathrm{f} 92 \mathrm{c} 8 \& \mathrm{e}=0240 \mathrm{fb} 2611$

GWEM (2017), Global Wellness Economy Monitor, Global Wellnes Institute, Empowering wellness Worldwide, Viewed March 18, 2017, www.globalwellnessinstitute.org

GWEM (2018), Global Wellness Economy Monitor, Global Wellnes Institute, Empowering wellness Worldwide, Viewed February 22, 2019, https://globalwellnessinstitute.org/industry-research/2018 global-wellness-economy-monitor/ 
ToSEE - Tourism in Southern and Eastern Europe, Vol. 5, pp. 547-566, 2019

M. Peršić, L. Halmi: ACCOUNTING INFORMATION FOR MANAGING SUSTAINABLE HEALTH ...

GWI (2018), Global Wellness Institute, Empowering Wellness Worldwide, Viewed February 03. 2019, https://globalwellnessinstitute.org/press-room/press-releases/wellness-now-a-4-2-trillion-globalindustry/

GWS (2015), Identifies Top 10 Future Shifts in Wellness, Global Wellness Summit, 2015 Summit Wrap-Up, Building a Well World, November 13-15, 2015, Proceedings of Global Wellness Summit, Mexico City, Mexico.

GWS (2018), Trends for 2018, Global Wellness Summit, viewed 02 March 2018, http://www.gllobalwellnesssumit.com/2018-global-wellness-trends

GWS \& GWI (2018), Wellness Economy Monitor 2018 Graphics, Viewed February 12. 2019 https://www.dropbox.com/sh/f7refr3a4zawjpk/AADVJJJVzqDyz6ahozzcqDQca?dl=0\&preview= globalwellnesseconomy2017_v2FINAL.pdf

GWTR (2018), Global Wellness Trends Report, Global Wellness Summit, viewed 22 February 2018 , http://www.globalwellness summit.com/2018-global-wellness-trends/

GWTR (2019) Global Wellness Trends Report, Global Wellness Summit, viewed 18 February 2019 https://www.globalwellnesssummit.com/2019-global-wellness-trends/download-report/

Hall, C. M. (2011), "Health and medical tourism - Kill or cure for global public health", Tourism Review, Vol. 66, No. 1-2, pp. 1-17.

Hamlin, L. (2012), "Patients Without borders: The Rise of Surgical Tourism", AORN Journal, Vol. 95, No. 4, pp. 529-534, doi: http://dx.doi.org/10.1016/j.aorn.2012.01.021

Health Programme (2014), Third Programme for the Union's action in the field of health 2014-2020 and repealing decision No 1350/2007/EC, Regulations EU No 282/2014 of the EU Parlament and the Council of 11 March 2014, Official Journal of the European Union p. L 86/1 - 86/13, Retrieves February 31, 2016 http://eur-lex.europa.eu/legalcontent/EN/ TXT/PDF/?uri=CELEX:2014R0282 \&qid $=1466711838512 \&$ from $=\mathrm{EN}$

Hoque, M.E. (2017), "Why Company Should adopt Integrated Reporting”, International Journal of Economics and Financial Issues, ISSN 2146-4138, Vol. 7, No. 1, pp. 241-248.

Hoque, Z. (2006), Strategic Management Accounting, Concepts, Processes and Issues, 2nd Edition, Pearson Education Australia, Frenchs Forest, Australia.

IIRC (2013), Business and Investors explore the sustainability perspective of Integrated Reporting. The IIRC Pilot Programme Yearbook 2013, Viewed November 23, 2017. http://integratedreporting.org/wpcontent/uploads/2013/12/IIRC-PP-Yearbook-2013_PDF4_PAGES.pdf

IIRC (2016), Journey to Breakthrough, IIRC Integrated Report 2016, Viewed May 22, 2017, http://integratedreporting.org/wp-content/uploads/2017/07/IIRC_IR2016_IntegratedReport.pdf

IR Framework (2013), The International "IR" Integrated Reporting Framework, The International Integrated Reporting Council (IIRC). https://integratedreporting.org/wp-content/uploads/2013/12/13-12-08 THE-INTERNATIONAL-IR-FRAMEWORK-2-1.pdf

IR (2016), Creating Value - The cyclical power of integrated thinking and reporting, IIRC - The International Integrated Reporting Council, Viewed January 15, 2017, http://integratedreporting. org/wpcontent/uploads/2016/11/CreatingValue_IntegratedThinking.pdf

ISO 17679 (2016), Tourism and related services - Wellness spa - Service requirements, Technical Committee ISO/TC 228 Tourism and related services, ICS: 03.200.01 Leisure and tourism in general 03.080.30 Services for consumers, Viewed October 14, 2017, https://www.iso.org/ standard/60243.html

ISPA (2015), The International Spa Association - Research, Viewed December 21, 2015, http://experienceispa. com/resources/research

ITU (2016), "Measuring ICT Development: New Trends, new Challenges", International Telecommunication Union News, Special Edition World Telecommunication / ICT Indicators Symposium, Hiroshima, Japan, No. 1, pp. 1-27.

Johnston, K., Puczko, L., Smith, M., Ellis, S. (2011), Wellness Tourism and Medical Tourism: Where Do pas Fit?, research report, New York, Global SPA Summit (GSS)

Johnston, R., Crooks, V. A, Snyder, J. \& Kingsbury, P. (2010), "What is Known About the Effects of Medical Tourism in Destination and Departure Countries? - A Scoping Review", Equity Health, Vol. 9, No. 1, pp. 1-24, doi: http://dx.doi.org/10.1186/1475-9276-9-24PMID:21047433

Jonston, T. \& Garman, A. (2010), "Impact of Medical Travel on Imports and Exports of Medical Services", Health Policy, Vol. 2, No. 98, pp. 171-177.

Keck, A. (2010), Field of Health Tourism - A Practical Handbook for Beginners //Geschäftsfeld Gesundheitstourismus - Ein Praxishandbuch für Einsteiger, Oldenburg, Oldenburgishe Industrieund Handelskammer, Metropole Nordwest. 
ToSEE - Tourism in Southern and Eastern Europe, Vol. 5, pp. 547-566, 2019

M. Peršić, L. Halmi: ACCOUNTING INFORMATION FOR MANAGING SUSTAINABLE HEALTH ...

Khan, M., Serafeim, G. \& Yoon A. (2015), Corporate Sustainability: First Evidence on Materiality, Harvard Business School Working Paper 15-073, pp. 1-37, Viewed January 24, 2018, https://dash.harvard.edu/bitstream/ handle/1/14369106/15-073.pdf?sequence=1

KHTC (2014), Kvarner Health Tourism Cluster // Klaster zdravstvenoga turizma Kvarnera, viewed 30 April 2017, http://www.kvarnerhealth.hr/o-nama

KHTG (2017), Kvarner Health Tourism Guide - Health \& Holiday all in One Place, Kvarner Health Tourism Cluster, pp. 1-52, viewed 12 February 2018, www.kvarnerhealth.hr

KHW (2012), Kvarner Health \& Wellbeing, Kvarner Tourist Board // Turistička Zajednica Kvarnera, viewed 10 February 2017 http://www.kvarner.hr/en/brosure/en/health_tourism/files/assets/basic-html/page16.html

KSOTMP (2016), Kvarner Strategic and Operative Marketing Plan of Tourism Development // Strateški marketinški plan razvoja turizma Kvarnera, sa strateškim i operativnim marketing planom 2016. 2020, Official County Gazette - OCG // S1. novine PGŽ NO 28/16, Faculty of Tourism and Hospitality Management Opatija, Institut for Tourism Research Zagreb, Primorsko-Goranska County, Kvarner Tourist Board, pp. 1-414, viewed 12 September 2017, http://www.sn.pgz.hr/default.asp?Link=odluke\&id=34452 \& http://www2.pgz.hr/doc/dokumenti/2016-11-strat-plan-turizma-2016-2020.pdf

Law, R., Leung, R. \& Buhalis, D. (2009), "Information Technology Applications in Hospitality and Tourism: A Review of Publications 2005 to 2007, Journal of Travel \& Tourism Marketing, Vol. 25, No. 5, pp. 599-623.

Local Measure (2018), What's In \& What's Out for Wellness in 2018, Top Wellness Trends, Local Measure viewed 12 January 2018 , https://get.localmeasure.com/hubfs/Insights/Wellness/eBook-Whats_ In Out Wellness Tear Sheet.pdf

Lončarić, D. \& Radetić, N. (2015), "The Implementation of E-Marketing in the Hotel Industry: The Case of Istria County", Zbornik Veleučilišta u Rijeci, Vol. 3, No. 1, pp. 15-26.

Mainil, T., Eijgelaar, E., Klijs, J., Nawijn, J. \& Peeters, P. (2017), Health tourism in the EU_A general investigation, Research for TRAN Committee, European Parliament, Policy Department for Structural and Cohesion Policies, Brussels.

Mio, Ch. (Eds) (2016), Integrated Reporting - A New Accounting Disclosure, Palgrave Macmillan Publishers Ltd. London, https://doi.org/10.1057/978-1-137-55149-8

MT FAQ (2017), Medical Tourism FAQ's, Medical Tourism Association, The Medical Tourism Magazine, viewed 12 February 2018, http://www.medicaltourismassociation.com/en/medical-tourism-faq-s. html

MTDG (2015), Medical Tourism Destination Guide, Medical Tourism Association ${ }^{\circledR}$ Destination Guides, No 561-791-2000, viewed 13 May 2017, www.MedicalTourismAssociation.com

MTT (2016), Medical Tourism trends 2017, Viewed April 22, 2017, http://ftnnews.com/health-a-spa/30526 2017-medical-tourism-trends.htm

NWI (2012), About Wellness; Six Dimensions of Wellness Model C 1976 by Bill Hettler, Stevens Point WI, National Wellness Institute, Inc. \& National Wellness Organisation, Viewed January 02. 2016, http://www. nationalwellness. org/index.php?id_tier=2\&id_c=26

PBB (2014), Patients Beyond Borders - Medical Tourism Statistics \& Facts, The Accreditation Association of Ambulatory Health Care (AAAHC) and The American Association for Accreditation of Ambulatory Surgery Facilities (AAASF) Joint Commission International (JCI), viewed 12 January 2016, http://www.patientsbeyondborders.com/medical-tourism-statistics-facts

Peršić, M. (2012), Health tourism in function of the tourist destinations development //Zdravstveni turizam u razvoju turističke destinacije, Hospitality and Tourism // Ugostiteljstvo i turizam, LX (4-5), pp. 4044.

Peršić, M., \& Janković, S. (2012), “Assesment of the Opportunities and Assumptions of Croatian Health Tourism Development”, Journal of Business Management, Vol. 6, pp. 88-104.

Peršić, M., Janković, S. (2014), "Research of Precondition for Sustainable Development of Health Tourism Destination" // Istraživanje pretpostavki za održivi razvoja zdravstveno-turističke destinacije, In: Zbornik 5. znanstveno-stručnog skupa - Aktualnosti hrvatskog pomorskog prava, prava mora, prava u turizmu, građanskog i upravnog prava - In memoriam prof. dr. sc. Vjekoslav Šmid, Grad Rab \& Pravni fakultet Sveučilišta u Splitu, pp. 341-360.

Peršić, M., Vlašić, D., Janković, S. (2016), "Importance of Accounting Information for Increasing Competitiveness of Health Tourism - Case Study Croatia", In: Proceedings of EuroCHRIE 2016 Conference - What's Going Well in Hospitality, Tourism and Events?, CHRIE \& METU _The Hospitality \& Tourism Educators and Budapest Metropolitan University, Budapest, pp. 1-16, http://eurochriebudapest2016.org/ 
ToSEE - Tourism in Southern and Eastern Europe, Vol. 5, pp. 547-566, 2019

M. Peršić, L. Halmi: ACCOUNTING INFORMATION FOR MANAGING SUSTAINABLE HEALTH ...

Peršić, M., \& Halmi, L.(2016), "Disclosing non-financial information in companies' reports in Croatia", Copernican Journal of Finance \& Accounting, Vol. 5, No. 2, pp. 181-200, http://dx.doi.org/10.12775/CJFA.2016.022

Peršić, M. \& Vlašić, D. (2017), "Health Tourism Development - Specifics of Croatian Health / Spas / Healing Resorts and Special Hospitals - State and Possibilities", In: International Scientific Conference Contemporary Tourism - Traditions and Innovations, Sofia University "St. Kliments Ohridski" Geography of Tourism Department, pp. 443-444.

Peršić, M. (2018), Situacijska analiza - Empirijsko istraživanje dostignutoga stupnja razvoja zdravstvenoturističke ponude Kvarnera \& Ocjena mogućnosti implementacije uspješnih modela razvijenih konkurentskih destinacija zdravstveno-turističke ponude, projekt Fakulteta za menadžment u turizma i ugostiteljstvu i Turističke zajednice Kvarnera.

RDS (2015), Regional Development Strategy // Razvojna strategija Primorsko-goranske županije 2016. - 2020, viewed 24 October 2017 , http://www2.pgz.hr/poziviskupstina/1317/skupstina22/TOCKA1-PRILOG.pdf

RSHID (2013), Regional Strategy of Health Industry Development // Strategija razvoja zdravstvene industrije Primorsko-goranske županije za razdoblje 2013 - 2020 godine, viewed 30 May 2017 http://www2.pgz.hr/doc/dokumenti/Strategija-razvoja-zdravstvne-industrije-PGZ-za-20132020.pdf

Ruggeri, K., Zališ, L., Meurice, Ch.R., Hilton, I., Ly T.L., Zupan, Z. \& Hinrichs, S. (2015), "Evidence on Global Medical Travel, Policy \& Practice”, Bulletin of the World Health Organization, WHO, pp 785-789, doi: http://dx.doi.org/10.2471/BLT.14.146027

Rulle, M. (2008), The health tourism in Europe - trends and diversification strategies // Der Gesundheitstourismus in Europa - Entwiklungstendenzen und Diversifikations-strategien, II Ed. Wien, Profil Verlag.

Smith, M. \& Puczko, L.(2009), Health and Wellness tourism, Butterworth-Heinemann, Elsevier.

Snyder, J., Crooks, V., Johnston, R. \& Kingsbury, P. (2013), "Beyond sun, sand, and stitches: Assigning Responsibility for the Harms of Medical Tourism", Bioethics, Vol. 27, No. 3, pp. 233-242.

Speier, A.R. (2011), "Health tourism in a Czech health spa", Anthropology \& Medicine, Vol. 18, No. 1, doi: http://dx.doi.org/10.1080/ 13648470.2010.525879

Tabacchi, M.H. (2010), “Current Research and Events in the Spa Industry”, Cornell Hospitality Quarterly, Vol. 51, No. 1, pp. 102-117.

TE (2010), Europe, the world's No 1 tourist destination - a new political framework for tourism in Europe, European Commission, Brussels, 30. 06. 2010. COM 352 2010), The European economic and socia committee and the Committee of the regions, viewed 12 March 2016 , http://eur-lex.europa.eu/legalcontent/EN/TXT/PDF/?uri=CELEX:52010DC0352 \& from=ENd

Voigt, C., Laing, J., Wray, M., Brown, G., Howat, G., Weiler, B., Trembath, R. (2010), Health Tourism in Australia: Supply, Demand and Opportunities, Gold Coast, Queensland, CRS for Sustainable Tourism, National Library of Australia.

Woodman J. (2016), Medical Tourism Statistic \& Facts," Patients Beyond Borders" - The most trusted resource in medical travel, viewed 11 May 2017, http://www.patientsbeyondborders.com/medical-tourismstatistics-facts

Youngman, I. (2018), "Medical Tourism Facts and Figures 2018: Country sample", IMTJ - International Medical Travel Journal, The World Leading Journal for the Medical travel Sector, Viewed January 15, 2018, https://www.imtj.com/resources/ medical-tourism-research-facts-and-figures-2018/ 
ToSEE - Tourism in Southern and Eastern Europe, Vol. 5, pp. 547-566, 2019

M. Peršić, L. Halmi: ACCOUNTING INFORMATION FOR MANAGING SUSTAINABLE HEALTH ...

Milena Peršić, PhD, Full Professor

University of Rijeka

Faculty of Tourism and Hospitality Management

Accounting Department

Naselje Ika, Primorska 42, P.O.Box 97, 51410 Opatija, Croatia

Phone: +385 51294698

E-mail: milena.persic@fthm.hr

Lahorka Halmi, PhD Candidate

Karlovac University of Applied Sciences

Trg J.J. Strossmayera 9, 47000 Karlovac, Croatia

Phone: +38547843546

E-mail: lahorka.halmi@vuka.hr 